\title{
DESIGN AND RESEARCH ON THE FIRST POLISH FRP COMPOSITE ROAD BRIDGE
}

Tomasz Siwowski, University Professor, Rzeszów University of Technology, Poland Damian Kaleta, Principal Bridge Designer, Promost Consulting, Rzeszów, Poland Mateusz Rajchel, PhD Student, Rzeszów University of Technology, Poland

\section{Abstract}

The main goal of the research project was to develop and demonstrate the first Polish FRP composite road bridge, starting from concept design and material research, and going thru manufacturing technique selection, detailed FEM analysis and structural testing of elements. The R\&D project comprises also the proof test of the completed bridge as well as structural monitoring in exploitation period. The objective of the paper is the description of the bridge and its structural solutions, i.e. FRP box girders and lightweight concrete deck slab acting compositely. Further the FEM analysis of the girder and the bridge span made on design stage has been presented. The VARTM manufacturing technique was used for girders production. Its main steps have been also presented. Finally the research on the new FRP box girder with LRC slab (hybrid girder) has been briefly showed. The full scale prototype girder with the total length of $22 \mathrm{~m}$ was tested to evaluate its carrying capacity, modes of failure, basic dynamic parameters as well as overall behaviour under ultimate static load. The FRP girder met the prescribed serviceability and safety criteria. The FEM model of the girder was validated against testing results and was further used for bridge design. Thanks to R\&D project the first Polish FRP bridge is likely to be built late autumn 2015. The output of the research project gives a very promising future for the FRP composite bridge application. The research works showed in the paper have been partially financed by the Polish National Centre for Research and Development in the frame of the research project "ComBridge" (www.com-bridge.pl).

Keywords: FRP composite bridge, FEM analysis, structural testing, validation,

\section{INTRODUCTION}

Lightweight and high strength fibre reinforced polymer (FRP) composites are adding years to the life of critical infrastructure throughout the world, while minimizing ongoing maintenance costs. First used in the 1950 s for ships, FRP composites have undergone ongoing development to become highly valued in aerospace and military applications for their lightweight and high strength 
properties. Civil infrastructure applications began in the 1980s with research on carbon fibre reinforced polymer (CFRP) strengthening of bridges, buildings and other structures, and the design and construction of the first FRP pedestrian bridge in China [1]. More recently, pedestrian and road bridges, bridge enclosures and other structural applications have been undertaken using FRP composite components.

FRP is a composite material made of a polymer matrix reinforced with fibres. The fibres are usually glass, carbon or aramid and have many advantages over other more traditional construction materials due to their high strength to weight ratio, ability to be moulded into various shapes and resistance to environmental conditions that therefore result in low maintenance costs. Structural applications of fiber reinforced polymer (FRP) composites have recently been attractive in the civil engineering community due to their superior material properties such as high specific stiffness (CFRP), high specific strength, and high corrosion resistance. However, all-composite structural systems have specific shortcomings such as high initial costs, low stiffness (GFRP) and existence of catastrophic failure modes. To make the best use of materials and overcoming the above shortcomings, combinations of FRP and conventional materials have recently been investigated by a number of researchers [2]. According to them the most effective use of FRP composites in civil structural applications is in the form of a hybrid construction with concrete. The review of various FRP-concrete composite beam/deck systems and their construction applications in civil engineering is presented, and several problems in the future research are discussed f.e. in [3],[4],[5].

The main goal of the research project carried out by the Rzeszow University of Technology, Poland, was to develop and demonstrate the first Polish FRP composite road bridge. The innovative hybrid idea of a FRPconcrete composite structural system for bridge girders was proposed. The objective of the paper is the description of the bridge. The detailed FEM analysis, VARTM manufacturing technique used for girders production and some results of the initial research on the hybrid box girder have been also briefly presented. The output of the research project gives a very promising future for the FRP composite bridge application in Poland. The first Polish FRP bridge is likely to be built late autumn 2015 according to description below.

\section{FRP GIRDER DESIGN}

\subsection{Bridge and girder geometries}


ROMANIAN JOURNAL

OF TRANSPORT INFRASTRUCTURE

The bridge deck with a span of $22,00 \mathrm{~m}$ and a width of $10,44 \mathrm{~m}$, is formed by four simply supported FRP girders with an overlying $0,18 \mathrm{~m}$ thick lightweight concrete slab reinforced longitudinally and transversally with GFRP bars (Fig.1). The FRP girder has a U-shape cross section with a maximum width of $1550 \mathrm{~mm}$ and a depth of $1020 \mathrm{~mm}$. The top flanges are $350 \mathrm{~mm}$ width each one, and the bottom flange is $735 \mathrm{~mm}$ width. The top flanges and the webs have a thickness of $23 \mathrm{~mm}$, while the bottom flange is $19 \mathrm{~mm}$ thick. The top flange is made of GFRP but the bottom one has mixed CFRP/GFRP structure. The web is made as a sandwich panel with foam layer $15 \mathrm{~mm}$ thick between two glass fabrics. To increase the torsional stiffness of the girder and prevent shearbending buckling of its webs, six internal diaphragms are placed along the length of the girder. The diaphragms are built as a sandwich panels with the structure alike the webs. A sandwich panel is also adhesively connected to the top flanges of the girder to be used as a formwork during the concrete slab casting. The top reinforced concrete slab is connected to the FRP girder through galvanized steel shear connectors. The support zones of the FRP girder are filled with lightweight concrete to create support cross-beams and to ensure transverse stiffens of the span.

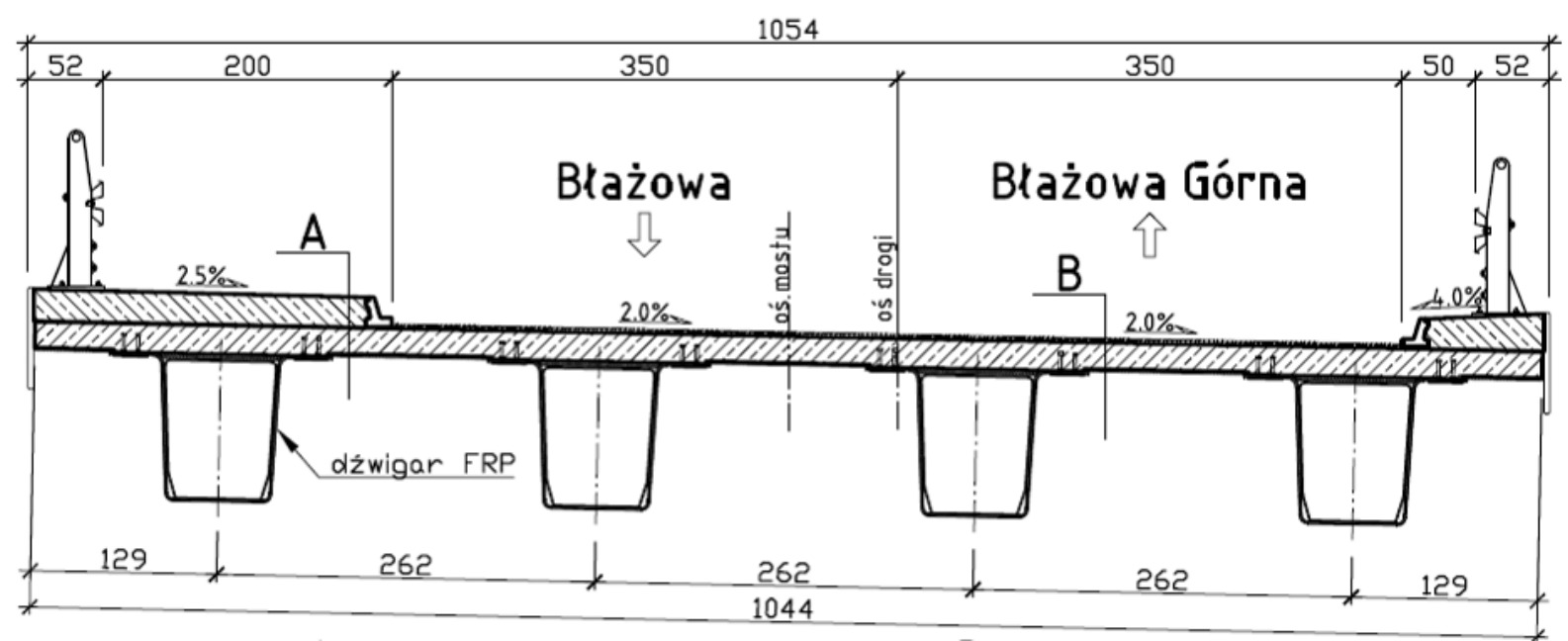

Figure 1. Cross-section of the bridge deck

\subsection{Laminates and their mechanical properties}

The FRP laminates which form the walls of the box girder have vinyl ester matrix and hybrid glass-carbon reinforcement. Carbon and E-glass in the form of a woven fabrics were chosen as the reinforcement of FRP. Vinyl ester resin was chosen as the matrix. The advantage of vinyl ester resins is that it 
ROMANIAN JOURNAL

OF TRANSPORT INFRASTRUCTURE

combines the positive aspects of epoxy and polyester. The lower FRP flange has got the hybrid structure and comprises total 28 layers (17 layers of carbon fibers with $0^{\circ}$ orientation and 11 layers of E-glass fibers with $\pm 45^{\circ}$ orientation). The top FRP flange has got 32 layers of E-glass fibers with $0^{\circ}$ and $\pm 45^{\circ}$ orientation. The web has got 9 layers of $E$-glass fiber with $\pm 45^{\circ}$ orientation and foam with a thickness $15 \mathrm{~mm}$.

The mechanical properties of these laminates were determined with the aid of the classical laminate theory [6], starting from the experimental characterization of the unidirectional lamina and the selected laminate stacking sequences. To determine the mechanical properties of a laminate tensile tests were performed using universal testing machine. The results are presented in Table 1 and 2.

Table 1. The material constants

\begin{tabular}{|c|c|c|c|c|c|c|c|c|c|}
\hline \multirow{3}{*}{$\dot{\mathrm{Z}}$} & \multirow{3}{*}{ 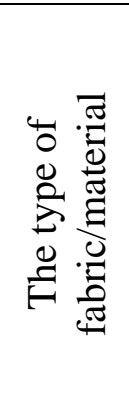 } & \multirow{2}{*}{ - } & \multirow{2}{*}{$\begin{array}{l}\frac{\overrightarrow{0}}{000} \cdot \frac{0}{\pi} \\
\frac{0}{3} \\
-\end{array}$} & \multirow{2}{*}{ 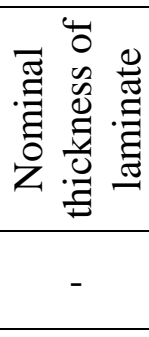 } & \multicolumn{2}{|c|}{ 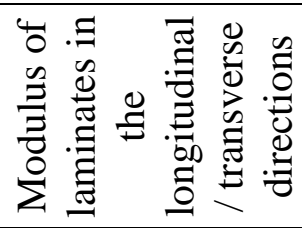 } & \multicolumn{2}{|c|}{$\begin{array}{l}\infty \\
\tilde{0} \\
\infty \\
0 \\
0 \\
0 \\
0\end{array}$} & \multirow{2}{*}{ 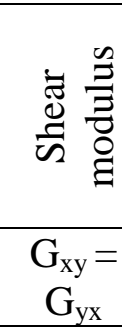 } \\
\hline & & & & & $\mathrm{E}_{\mathrm{x}}$ & $\mathrm{E}_{\mathrm{y}}$ & xy & $y x$ & \\
\hline & & {$[\mathrm{deg}]$} & $\begin{array}{l}{[\mathrm{kN} /} \\
\left.\mathrm{m}^{2}\right]\end{array}$ & {$[\mathrm{mm}]$} & [GPa] & [GPa] & [-] & {$[-]$} & [GPa] \\
\hline 1 & ass & \pm 45 & 1200 & 0,8 & 12,06 & 12,06 & 0.4 & 0 , & 3,0 \\
\hline 2 & Glass & 0 & 1200 & 0,80 & 42,13 & 10,87 & 0,29 & $\overline{0,0}$ & 2,71 \\
\hline 3 & Carbon & 0 & 600 & 0,60 & 115,76 & 5,72 & 0,41 & 0,021 & 3,32 \\
\hline
\end{tabular}

Table 2. The material strength

\begin{tabular}{|c|c|c|c|c|c|c|c|}
\hline \multirow{3}{*}{$\dot{z}$} & \multirow{3}{*}{ 莺 } & \multirow{3}{*}{ 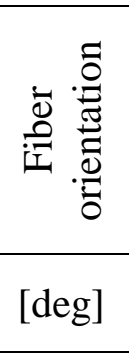 } & \multicolumn{4}{|c|}{ Normal strength } & \multirow{2}{*}{ 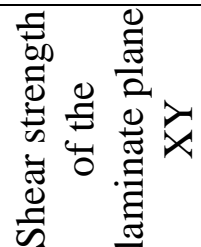 } \\
\hline & & & \multicolumn{2}{|c|}{ 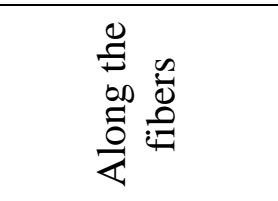 } & \multicolumn{2}{|c|}{ 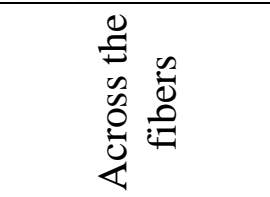 } & \\
\hline & & & $\begin{array}{c}\mathrm{X}_{\mathrm{t}} \\
{[\mathrm{MPa}]}\end{array}$ & $\begin{array}{c}\mathrm{X}_{\mathrm{c}} \\
{[\mathrm{MPa}]}\end{array}$ & $\begin{array}{c}\mathrm{Y}_{\mathrm{t}} \\
{[\mathrm{MPa}]}\end{array}$ & $\begin{array}{c}\mathrm{Y}_{\mathrm{c}} \\
{[\mathrm{MPa}]}\end{array}$ & $\begin{array}{c}S_{x y} \\
{[\mathrm{MPa}]}\end{array}$ \\
\hline 1 & $\begin{array}{l}\text { Glass } \\
1200 \mathrm{~g} / \mathrm{m}^{2}\end{array}$ & \pm 45 & 520,0 & 320,0 & 520,0 & 320,0 & 60,0 \\
\hline 2 & $\begin{array}{l}\text { Glass } \\
1200 \mathrm{~g} / \mathrm{m}^{2}\end{array}$ & 0 & 855,0 & 537,0 & 44,0 & 84,0 & 25,0 \\
\hline 3 & $\begin{array}{l}\text { Carbon } \\
600 \mathrm{~g} / \mathrm{m}^{2}\end{array}$ & 0 & 1150,0 & 464,0 & 12,0 & 94,0 & 54,0 \\
\hline
\end{tabular}




\subsection{Design models}

The one of the most important goals of the research project was to build and validate the detailed FEM models of the girder and the entire deck. These models were used to analyse parametrically the bridge superstructure in order to optimize its structural framework and to check design assumptions. To check the compliance of the bridge deck with the service and ultimate limit states as defined in the Polish code, two different FE models were implemented in SOFiSTiK to analyze bridge deck and girder behavior in the different steps of the bridge construction process and during service (Fig.2). The four-node shell finite elements (quad) were mainly used for girder discretization. The concrete slab and filling in the support regions were modelled using brick elements.

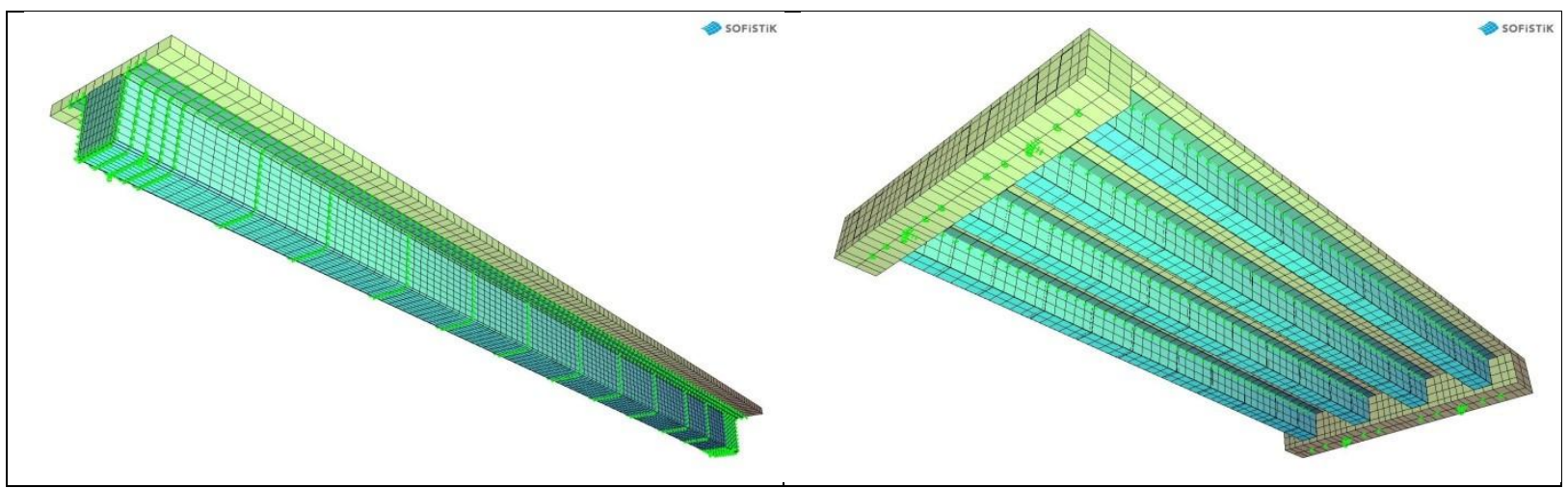

Figure 2. FEM models of the girder and the bridge deck

Material properties obtained from testing were used in FEM modelling. The orthotropic properties of the laminates having different properties in different directions of fibres were also taken into account. Thanks to software code possibilities, the exact layer structure of the laminates could be discretized and till 10 various layers (means: fabrics) were described in shell finite elements and thus enabled the exact material properties to be assumed in the girder FEM model with a combination of basic materials (for carbon and glass laminates, foam core and concrete).

The numerical model of the girder was also used for the second-order static and dynamic analysis under loading conditions predicted for large-scale testing (see below). The static performance of the girder was linear elastic in the full range of assumed loading. No local failures was also discovered within FEM model under this loading. The strength and stability of each girder section were numerically revealed and thus confirmed the proper design and appropriate structure framework of the girder. The very important initial design goal was to 
determine the number of internal diaphragms and eventually external ribs, that had to be applied to give additional stiffness of thin-wall sandwich webs.

The elaborated FEM girder model was also used for prediction of theoretical values of girders' self-frequencies, damping parameters and modes of vibrations. The comparison of theoretical values determined in FEM analysis with the values obtained in the real test in the laboratory was one of the main goals of the ongoing research. When the FEM model of the girder was validated against the test values, it would be used for girder's structural optimization and bridge deck design.

\section{GIRDERS MANUFACTURING PROCESS}

The girders were manufactured using the VARTM infusion process at the composite workshop of Mostostal Warszawa SA in Warsaw, Poland. This process was selected because, among processes used to manufacture FRP elements, is the most indicated to produce large dimension elements [7]. In fact, it is the process commonly employed to produce FRP boat hulls. According to this process, once the steel mould is properly prepared, the dry fabrics are piled up on it according to the stacking sequence defined in the design process. The dry fabrics are then covered by a plastic sheet that is sealed against the steel mould, forming what is known as a vacuum bag (Fig.3). The vacuum bag is provided with two series of valves, one connected to a vacuum pump and the other connected to a resin deposit. Once the vacuum is created in the bag, the resin valve is opened and the resin is sucked in the bag, impregnating the dry fabrics. The process must be properly designed in order to the resin impregnate uniformly the fabrics without leaving dry spots. The resin infusion allows placing all the dry fabrics in the mould and impregnating them in one shot, so the cost of the FRP girders is reduced compared to other manufacturing processes

After the dry fabrics get properly impregnated, the mould is covered with rock-wool blankets and the laminates are cured at $80^{\circ} \mathrm{C}$ during 9 hours blowing hot air under the blankets using industrial hot air generators. This curing process is the recommended by the resin supplier to obtain a glass transition temperature $\mathrm{T}_{\mathrm{g}}$ of $77-80^{\circ} \mathrm{C}$. After being cured, the girders are extracted from the mould and their edges trimmed to regularize them. A series of sandwich panels are then glued on top of the webs of the girders, to work as stay-in-place formworks during the casting process of the top slab. 


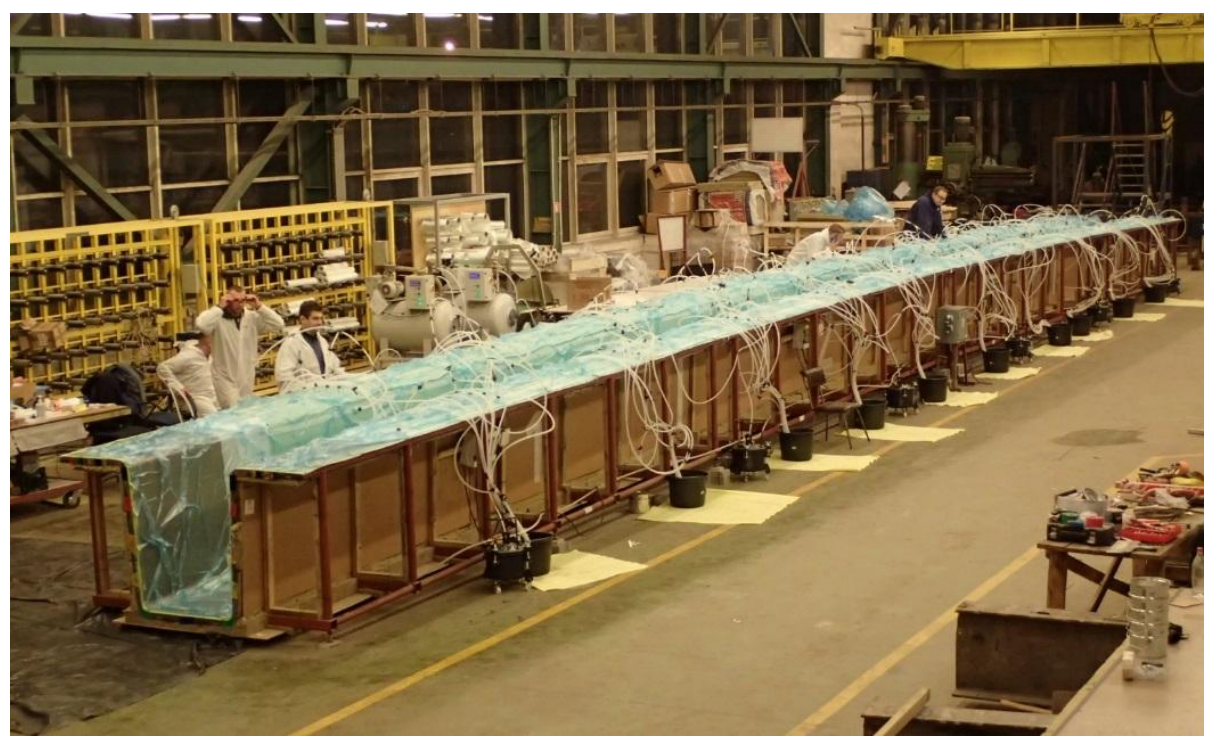

Figure 3. VARTM process of the girder

\section{THE PROTOTYPE GIRDER TESTING UNDER STATIC LOAD}

\subsection{Goals and instrumentation}

The main objective of prototype girder testing was to evaluate its behaviour under static load and to determine its real carrying capacity as well as modes of failure. The first step was to check the girder performance under the standard service load according to Polish code for road bridges. On this stage the validation of FEM model for design purposes was also undertaken. The initial static tests were followed by dynamic (modal) test of the girder. The main results of these tests allowed to establish the main dynamic characteristics of the prototype girder, i.e.: self-frequencies and corresponding modes, logarithmic decrement of damping and the level of vertical accelerations. Modal test was carried out in the scheme of SIMO test (single input multiple output). Finally, the girder was loaded with quasi-static loading until failure. The ultimate carrying capacity and modes of failure was the most interested output expected at this stage of research.

The 46 electrical resistance gauges were used for strain measurement: 11 strain gauges on the bottom flange, 6 on the top flange, 2 square rosettes on the web, 4 strain gauges on the shear studs and 13 gauges on the concrete slab deck. Displacements were recorded with 18 transducers along the length of the girder and at bearing pad location. Figure 4 shows the location of the strain gauges and displacement transducers in the middle of the girder, on the deck slab and the bottom flange. Calibrated load cells were used to monitor the load. Load, strain, 
ROMANIAN JOURNAL

OF TRANSPORT INFRASTRUCTURE

and displacement data were recorded one every second during testing with a digital data acquisition system. The modal hammers were used for girder excitation. Dynamic response was measured using a set of accelerometers as well as displacement transducers. With the results of structural acceleration in individual measuring points it was possible to determine the vibration modes for the first few self-frequencies of the girder and already mentioned dynamic parameters. Additionally AE data was recorded continuously with 92 channel Transportation Instrument monitoring system. The comprehensive laboratory tests of the girder model took place at the RUT structural laboratory (Fig.5).

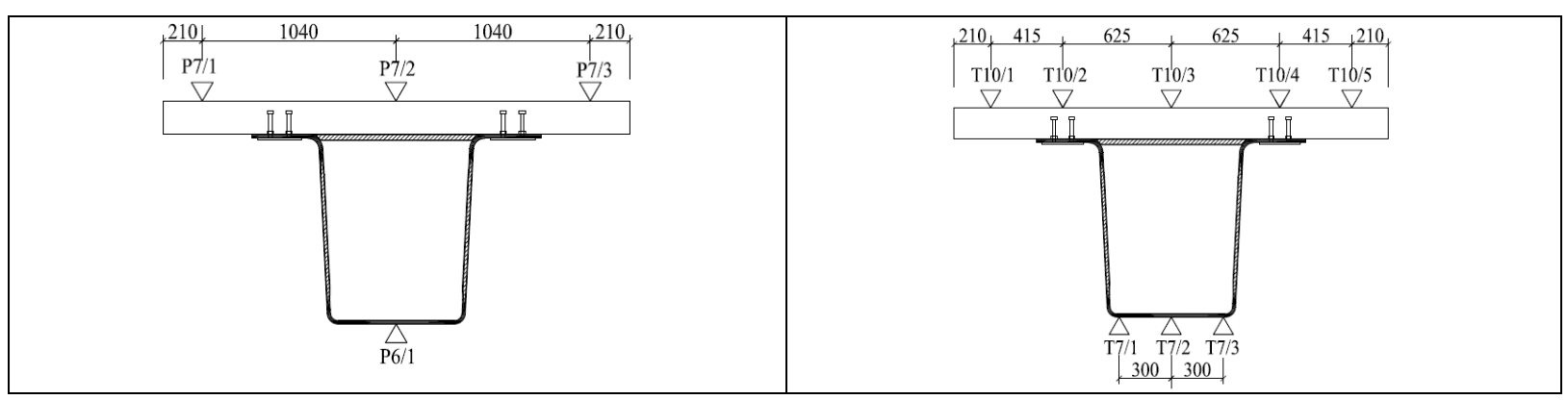

Figure 4. Instrumentation layout for the girder in the mid span $(\mathrm{P}-$ displacement transducers, $\mathrm{T}-$ strain gauges)
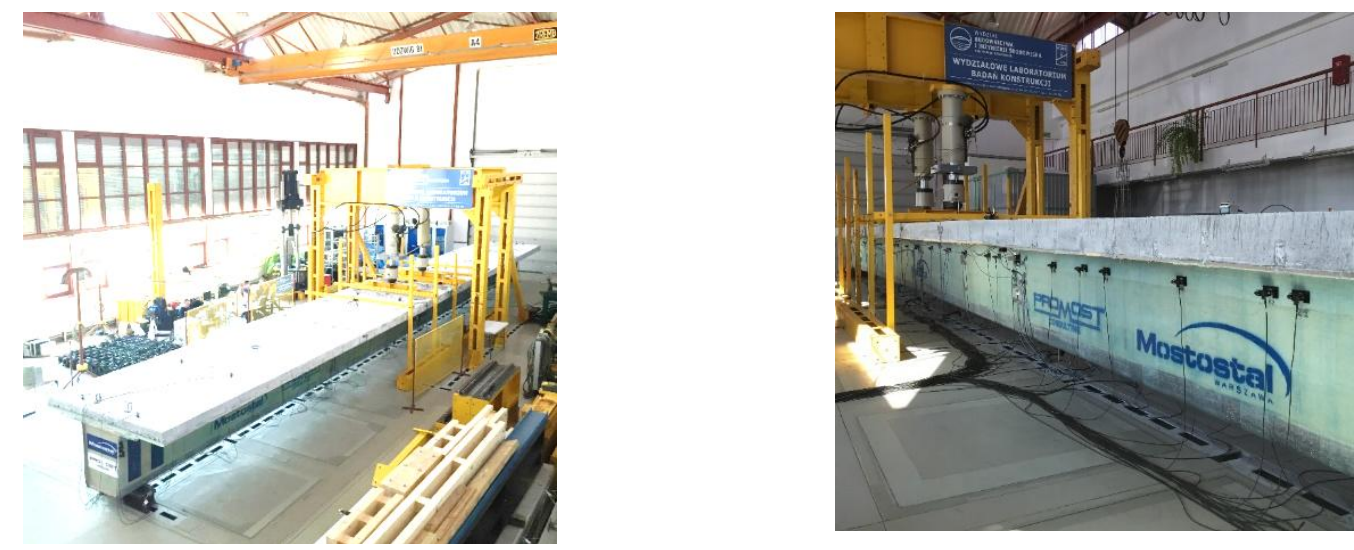

Figure 5. The girder under testing in the RUT laboratory

\subsection{Loading procedure}

The girder was tested in four-point bending using a $2 \times 630 \mathrm{kN}$ hydraulic actuators mounted on a steel frame (Fig.6). The load was distributed on the contact surface $2,50 \times 0,30 \mathrm{~m}$ of the deck slab. The girder was loaded in five stages with several increasing load levels. The first stage was to load the hybrid girder to the characteristic bending moment (total load: 390,2 kN). The second 
ROMANIAN JOURNAL

OF TRANSPORT INFRASTRUCTURE

stage was to load the hybrid girder to the design bending moment (total load: $584,0 \mathrm{kN}$ ). The third stage was to load to the hybrid girder to the characteristic shear force (total load: $810,0 \mathrm{kN}$ ) and the fourth stage was to load to the design shear force (total load: 1014,0 kN). The fifth stage was to load to the hybrid girder to the load testing machine actuators border equals $1260 \mathrm{kN}$. About 15 minute load holds were used for intermediate load steps and a $30 \mathrm{~min}$ load hold was used at the peak load. The purpose of load hold periods is to reduce nongenuine $\mathrm{AE}$ data and facilitate the damage, if any.

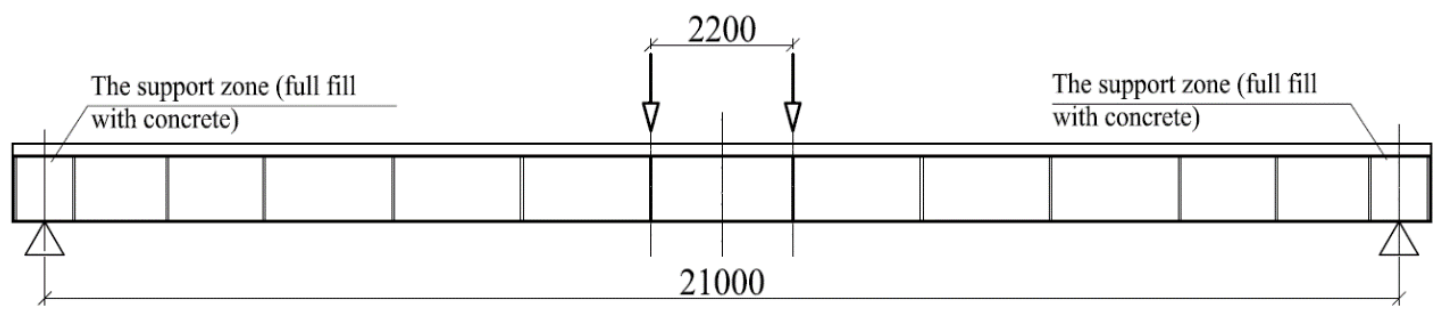

Figure 6. Loading scheme

\subsection{Main results}

Figure 7 shows the displacement plot in the measuring point located on the deck slab in the middle of the girder for the final load cycle $(0-1260 \mathrm{kN})$. Figures 8 and 9 show the strain plots in the measuring points located on the deck slab and bottom flange in the middle span of the girder for the final load cycle ( 0 $-1260 \mathrm{kN})$.

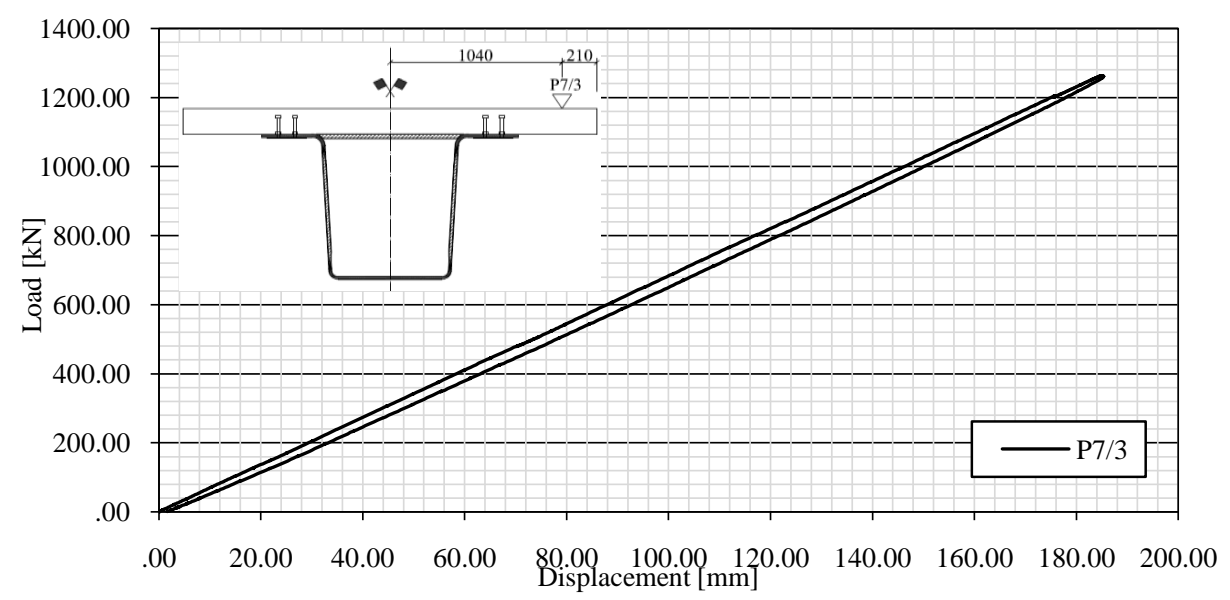

Figure 7. Mid-span displacement (mm) 
ROMANIAN JOURNAL

OF TRANSPORT INFRASTRUCTURE

The girder behaved linearly until the applied total load of $1260 \mathrm{kN}$ (Fig. 7, $8,9)$ and no residual displacement was observed after unloading. Under the maximum load $(1260 \mathrm{kN})$ the maximum strain of the bottom flange was equal $5,209 \%$, which corresponds to the tension stresses of $603 \mathrm{MPa}$ in the carbon laminate and $219,5 \mathrm{MPa}$ in glass laminate oriented $0^{\circ}$ in the direction of the longitudinal axis of the beam. The maximum stress of the carbon laminate was $52,6 \%$, while the glass laminate $25,7 \%$ of the characteristic strength of individual laminates according to Table 2. The concrete slab deck was not crushed under the load of $1260 \mathrm{kN}$. It should be noted that the girder reached the load-bearing capacity at the maximum range of actuators testing machine without undergoing the global destruction. The maximum girder's capacity established in the test (in terms of bending moment) was $\mathrm{M}_{\mathrm{n}}=5922,0 \mathrm{kNm}$, which is $323 \%$ of the characteristic bending moment for which the girder was designed.

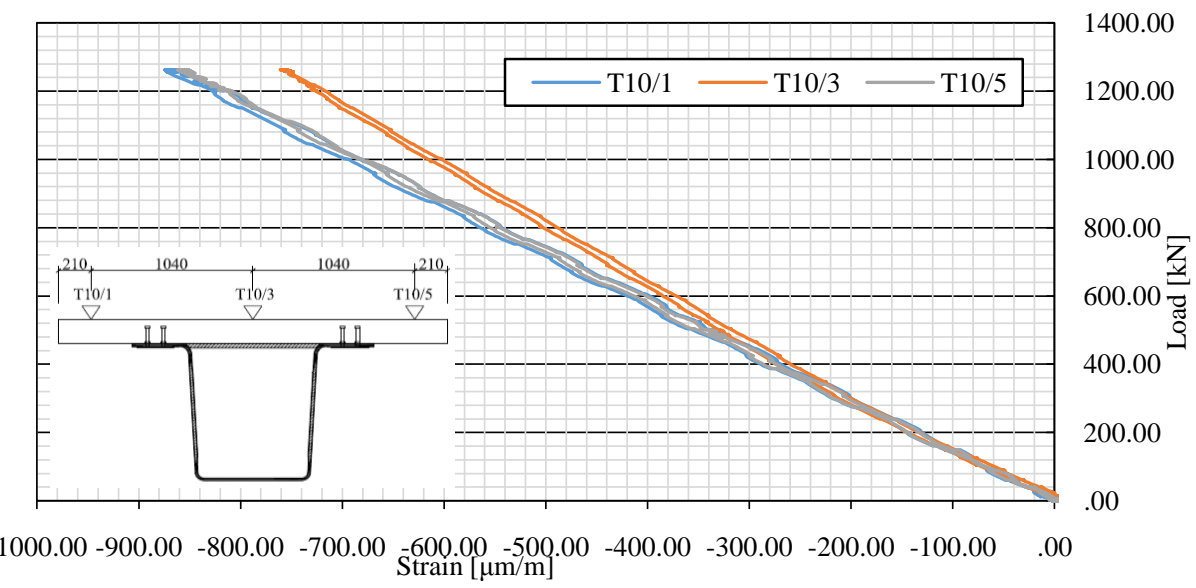

Figure 8. Strain plots in the deck slab in mid-span

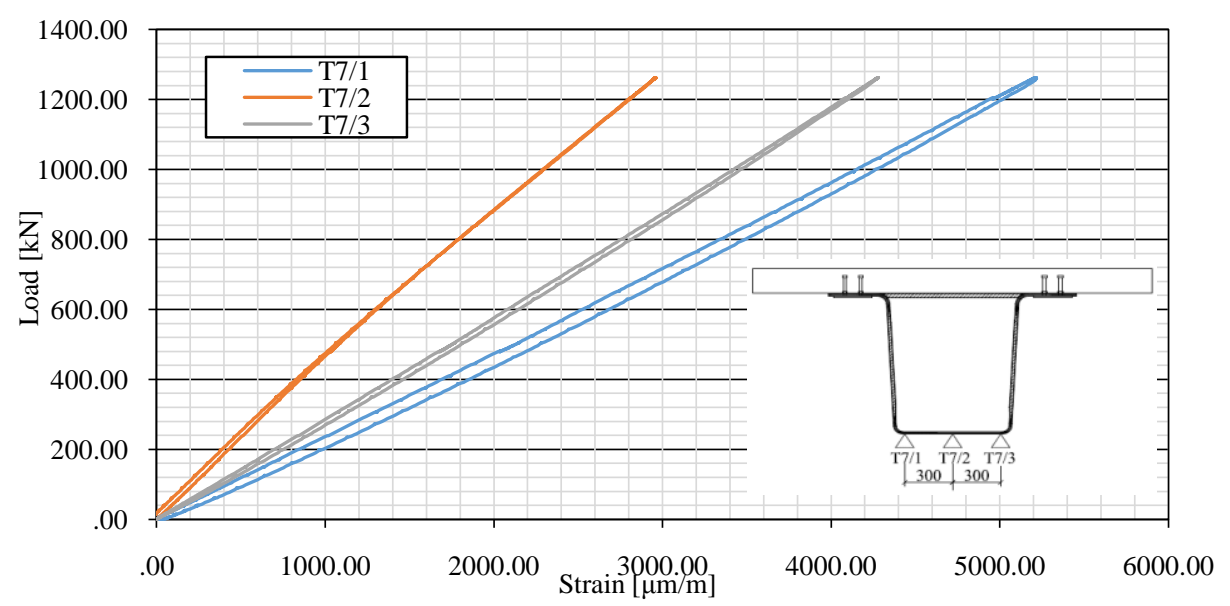

Figure 9. Strain plots in the bottom flange in mid-span 
ROMANIAN JOURNAL

OF TRANSPORT INFRASTRUCTURE

Under maximum load of $1260,0 \mathrm{kN}(2 \times 630,0 \mathrm{kN})$ the tested girder had no global destruction. However, the girder under a load of $1260 \mathrm{kN}$ suffered several small local damages in the form of:

- local inner and outer delamination in both flanges and at transition zone between web and upper flange (Fig.10, 11);

- failure of the epoxy adhesive joining steel plates of shear studs with the upper flange (Fig.12);

- local plastic deformation at the transition zone between the bottom flange and the web (Fig.12);

- scratch of laminate in the bottom flange.

Since any global failure during static test was not seen, the determination of damage in the girder was based on the AE data, what is not presented here.

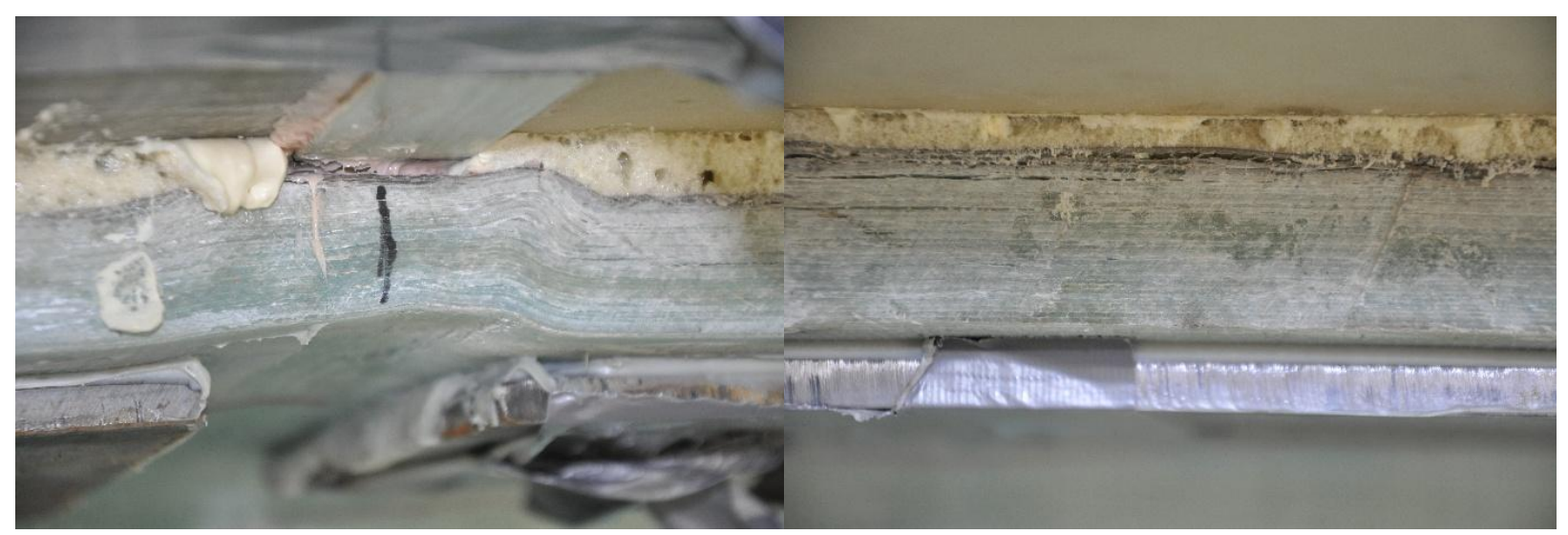

Figure 10. Local delamination of the upper flange in the middle of the girder (the location of structural notch made in the production stage of the girder)

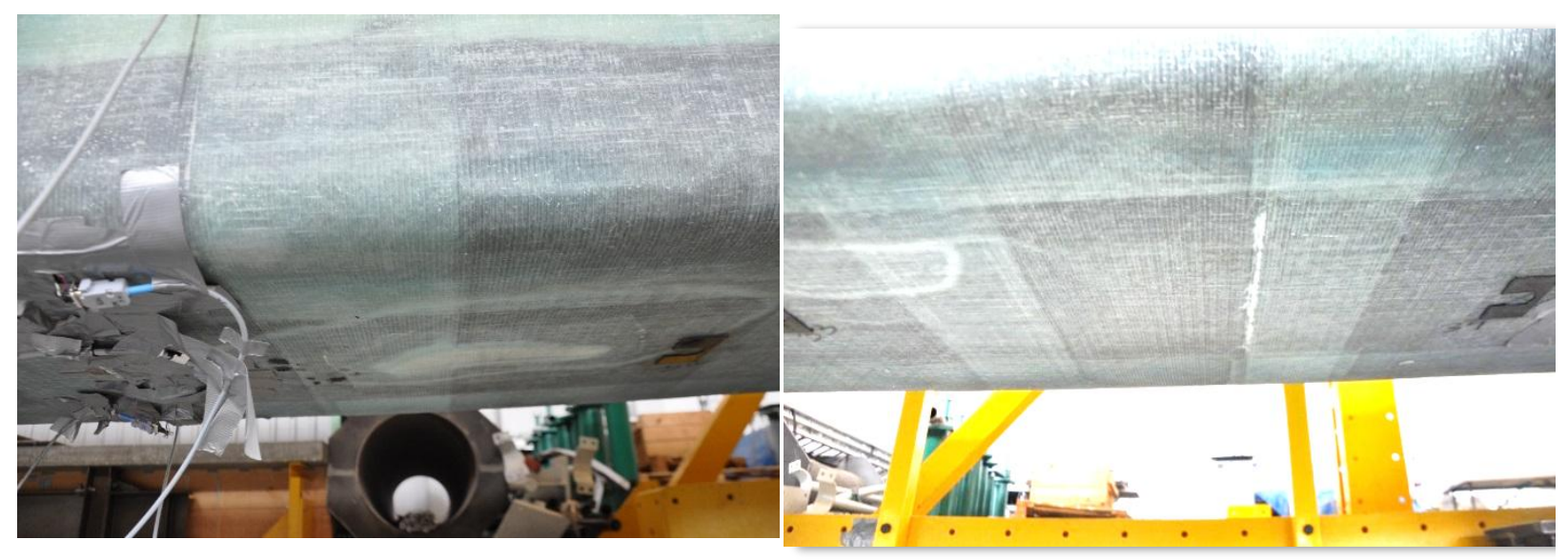


ROMANIAN JOURNAL

OF TRANSPORT INFRASTRUCTURE

Tomasz Siwowski, Damian Kaleta, Mateusz Rajchel

Design and research on the first polish FRP composite road bridge

Figure 11. Local delamination of the bottom flange at a distance of $7 \mathrm{~m}$ from the support (left) and scratch of laminate at a distance of $10 \mathrm{~m}$ from the support (right)

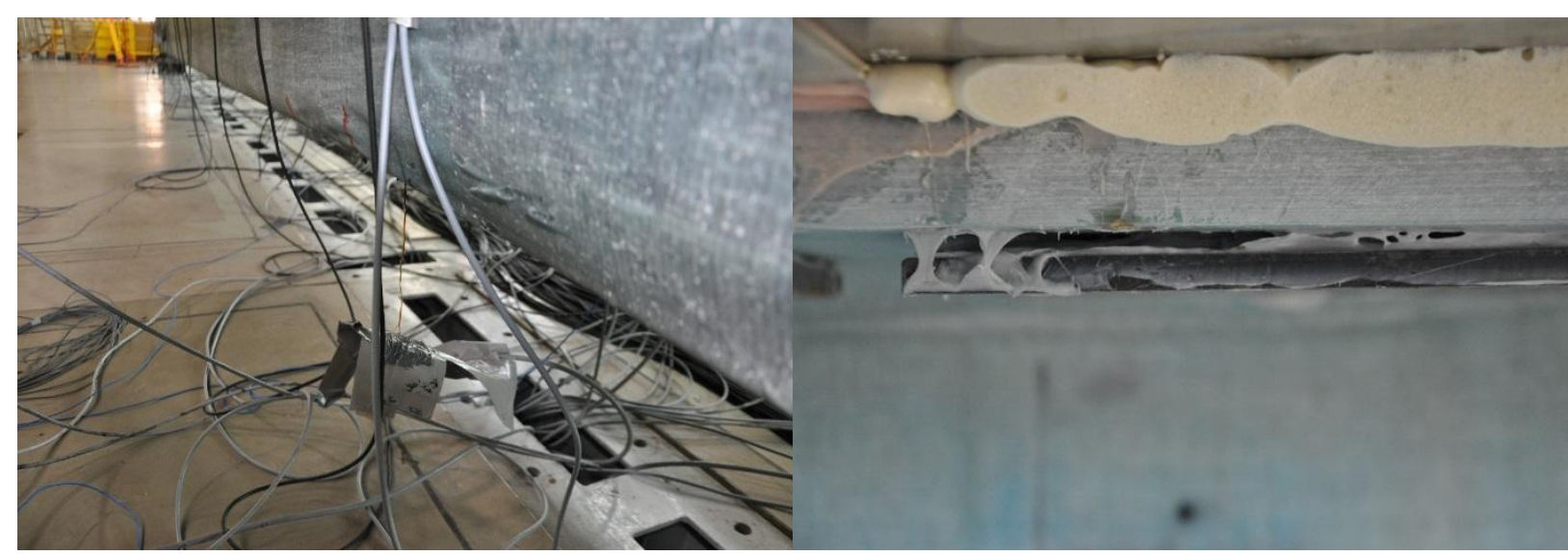

Figure 12. Plastic deformation at the transition zone between the bottom flange and the web in the middle of the girder (left) and the failure of epoxy adhesive joining upper flange and steel plate of shear stud

The comparison of experimental and numerical results showed acceptable accuracy of the FEM model of approximately $86 \%$ (minimum value).

\section{FINAL CONCLUSIONS}

The output of research project presented in this paper gives a very promising future for FRP girder application in road bridge construction. The proposed manufacturing techniques (VARTM) can be successfully applied in large scale bridge girder taking into account laminate thicknesses reaching about $20 \mathrm{~mm}$. In order to be more competitive with elaborated technology, there is a strong need for further research and demonstration in large scale projects. Moreover, there will be a still need to test the long term behaviour of this kind of structures as well as its real behaviour under the service loading. These tests are planned to be carried out in the next stages of the aforementioned research project.

The paper describes the results of studies determining the behavior of the FRP girder under static tests. Analyzing the results of a study involving the invocation of the maximum bending moment it must be stated that the girder was not globally destroyed under the total load of $1260 \mathrm{kN}$. In the entire load range the girder behaved perfectly linearly. When compared to the calculated design load, the ultimate (obtained in the test) load is approximately 2,16 times 
ROMANIAN JOURNAL

OF TRANSPORT INFRASTRUCTURE

Tomasz Siwowski, Damian Kaleta, Mateusz Rajchel

Design and research on the first polish FRP composite road bridge

greater and this indicates the original design of the girder was rather conservative. The proposed numerical model showed computing accuracy of approximately $86 \%$. In order to increase the accuracy of the FEM model, the analysis of composite material in a more advanced FEM program, which is dedicated to this type of material, should be undertaken.

The prototype FRP girder exhibited satisfying structural behaviour during the test and reasonable agreement with the predictions from the FE analysis. Thus the aims of the test were achieved (the results of the dynamic test are not reported in the paper). Since the test is unique, the results cannot be statistically verified and further testing will be necessary in the forthcoming work before decisive recommendations about the design of the bridge can be made.

This research was supported by the National Centre of Research and Development (NCBiR), Poland, in the frame of DEMONSTATOR+ programme, the project title: "ComBridge: Innovative road bridge with FRP composites" (No. UOD-DEM-1-041-/001).

\section{REFERENCES}

[1]. R. SHRIVASTAVA, U. GUPTA, U.B. CHOUBEY: "FRP: research, education and application in India and China in civil engineering". International Journal of Recent Trends in Engineering and Technology, No.1.6/2009.

[2]. M. ZOGH (ed.): "The International Handbook of FRP Composites in Civil Engineering”. CRC Press, Taylor \& Francis Group LLC, Boca Raton 2014.

[3]. L. YANG: "Research Status of FRP-Concrete Composite Beam/Bridge Deck Systems". Applied Mechanics and Materials, Vols. 587-589/2014.

[4]. A. HEJLL, B. TÄLJSTEN, M. MOTAVALLI: "Large scale hybrid FRP composite girders for use in bridge structures - theory, test and field application". Composites Part B: Engineering, Vol.36, No.8/2005.

[5]. P. ZIEHL, M. ENGELHARDT, T. FOWLER, F. ULLOA, R. MEDLOCK, E. SCHELL: "Design and Field Evaluation of Hybrid FRP/Reinforced Concrete Superstructure System". Journal of Bridge Engineering, 14(5)/ 2009.

[6]. E. J. BARBERO. “Introduction to Composite Materials Design”. CRC Press, 2011.

[7]. T. SIWOWSKI T., P. PONETA, M. KULPA: "Development and research on the innovative FRP girder for bridge application". The proceedings of the 37th IABSE Symposium "Engineering for Progress, Nature and People", Madrid, IABSE Report Vol.102, 2014. 